\title{
Biofortification of Oryza sativa L. with agri-food waste to improve the dietary value of crops
}

\author{
Parisa Ziarati $^{1,}$, Donya Moradi $^{2}$, Luis Cruz Rodriguez ${ }^{1,3}$, Bernhard Hochwimmer $^{4}$, \\ Viola Vambol $^{5,}$, Sergij Vambol $^{6}$ \\ ${ }^{1}$ Elidan genome sas, 1 avenue du Lycee, 77130 Montereau FY, France \\ ${ }^{2}$ Tehran Medical Sciences, Islamic Azad University, Tehran, Iran \\ ${ }^{3}$ ELIDAN America LLC, Fl, USA \\ ${ }^{4}$ Hochwimmer B. \& Asso. Pty Ltd, Albury, NSW, Australia \\ ${ }^{5}$ Department of Applied Ecology and Environmental Sciences, National University „Yuri Kondratyuk Poltava \\ Polytechnic", Poltava, Ukraine \\ ${ }^{6}$ Department of Life Safety, State Biotechnological University, Kharkiv, Ukraine \\ *corresponding author e-mail: ziarati.p@iaups.ac.ir; violavambol@gmail.com
}

Received: 11 September 2021 / Accepted: 25 October 2021

\begin{abstract}
Due to the low dietary value of crops, Zn-deficient soils and insufficient intake of other minerals, soil fortification is often necessary. Fortification is defined as the addition of one or more crucial nutrients to a food to reduce poverty in a population or specific population groups. Currently available technologies for rice fortification with vitamins and minerals are high-energy and time-consuming methods. Therefore, mineral enrichment of crops has received much attention from scientists. The originality of the current study consists in determining the optimal use of hard hazelnut shells, orange peel and rice husks for enrichment of paddy soil and simultaneous immobilization of heavy metals. The combination of the identified wastes, namely hazelnut shells, orange peel and rice husks, showed good potential for immobilization/ elimination or reduction of heavy metals to less than permissible limits. Therefore, the use of this combination could be an effective strategy to both introduce new micronutrients into rice grain and remove heavy metals.
\end{abstract}

Keywords: agro waste, rice, enriching foods, mineral elements, soil.

\section{Introduction}

Rice (Oryza sativa L.) is one of the most important cereals around the world, which is consumed by almost $40 \%$ of the world population as a main staple food. Rice provides the main part of daily human and animal calories, also $27 \%$ of dietary energy supply, $20 \%$ of dietary protein and $3 \%$ of dietary fat. Nutrients in rice include riboflavin, niacin, thiamine, vitamin $B$ and the precursor of vitamin A, with amounts of these nutrients depending on different factors. Analysis of literature sources suggests that the use of Agro/Food Wastes rich in useful minerals to enrich the
Oryza Sativa Rice crop with them is a rational solution. These include cultivar, agricultural practices, post-harvest conditions and handling. In recent years, different methods are used to improve the nutrients in food (Aleshkov et al., 2020; Biswal et al., 2019), including rice. This includes traditional breeding, genetic engineering and fortification as well as identifying compositional analysis of lesser-known rice cultivars, nutritional education and promotion (Dunna \& Roy, 2013; Rohman et al., 2014; Kennedy et al., 2003). As mineral micro-nutrients are not synthesized by the human body, so the daily diet should provide these minerals. Often soil fortification (Azam et al., 2021; Alloway, 2009) may be 
needed due to the low dietary value of crops, $\mathrm{Zn}$-deficient soils and insufficient intake of other minerals. Fortification is defined as the addition of one or more crucial nutrients to a food to reduce poverty in the population or specific population groups (Liyanage \& Hetteriarachchi, 2011). The price of food in recent years is increasing hunger and food poverty. Risk of poverty threatens poorer households, causing deficiencies of vitamins and minerals. Food of low nutritional values often substitutes expensive and nutrient rich foods like meat, fish, dairy products and fruits (Muthayya et al., 2014). Regular consumption of fortified food can help provide micro-nutrients needed for growth of children and to ensure pregnant women have adequate nutrients (Liyanage \& Hetteriarachchi, 2011). Rice is a good example of fortification with micro-nutrients due to its regular consumption (Rohman et al., 2014). The deficiency in nutrients; get inadequate nutrients by target population; the regular consumption of rice; the methods used in the fortified kernels and their sensory and physical kernels on the rice kernels; the availability and coverage of other fortified staple food; consumer acceptability; the mineral and vitamins supplements consumed by people; the executive possibility and the costs are factors that affect the decisions about the type and amounts of nutrients to supplement to fortified rice.

Successful implementation of a fortification program requires easy access to the product, consumer's understanding and demand for the product, government monitoring and support. Hot extrusion, cold extrusion, coating and dusting are current technologies available for rice fortification with vitamins and minerals. These are high energy and time-consuming methods (Kennedy et al., 2003). The study (Mahmoud et al., 2009) emphasizes that the last sixty years show decreases in the main mineral contents of crops such as $\mathrm{Ca}^{+2}, \mathrm{Mg}^{+2}, \mathrm{Na}^{+}, \mathrm{P}, \mathrm{Fe}^{+2}$, and $\mathrm{Cu}^{+2}$. Organic inputs are being proposed as an effective way to maintain soil fertility (Dar et al., 2019), which augment plant growth by supplying adequate secondary and micro-nutrient essentials. So boosting minerals in crops receives much attention from scientists (Dar et al., 2019). Hazelnut (Coryllus avellana L.) is the fruit of hazel trees, with the hard shell often being thrown away as waste. Hazelnut shells contain different levels of hemicelluloses, cellulose and lignin, based on variety, along with a good potential to remove toxic ions (Hebda et al., 2018; Cruz Lopes et al., 2012). Orange (Citrus sinesis) is a fruit that is cultivated in many countries. Also called pericarp, skin or rind, the orange peel forms a huge part of annual byproduct wastes. However, the orange peel is a rich source of phyto-chemicals (alkaloids, tannin, and saphonins), macro-nutrients (potassium, sodium, calcium, phosphorus and magnesium) and micro-nutrients (iron, zinc, copper, manganese and selenium) (Arora \& Kaur, 2017). Rice husk is an agricultural residue, with several million tons being generated annually. The proper reuse of hazelnut shells, orange peel and rice husk wastes offers renewable and cost-effective benefits, also reducing environmental pollution (Glushankova et al., 2018). This study determines optimal use of hard hazelnut shells, orange peel and rice husks to fortify paddy soil and also immobilize heavy metals at same time.

\section{Materials and Methods}

\section{Bio-sorbent \& Study Area}

Beginning in 2020, a field experiment was carried out at two rice fields of greater than 10 ha in Astara, Gilan Province, in the north of Iran ( $\left.38^{\circ} 25^{\prime} 45^{\prime \prime} \mathrm{N} 48^{\circ} 52^{\prime} 19^{\prime \prime} \mathrm{E}\right)$. This province is one of the 31 provinces in Iran. It lies along the Caspian Sea, just west of Mazandaran province, east of Ardabil province and north of Zanjan and Qazvin provinces (Fatahi et al., 2020). Rice has been cultivated in this region for many years, where some indigenous cultivars (land races) were conventionally bred by farmers. Astara has a humid subtropical climate with relatively cold, wet winters and hot, humid summers having 112 rainy days on average.

Rice husk ( $\mathrm{RH}$ ) was obtained in 2020 from two rice mills in the north of Iran and from the rice paddies at the study location. This was approximately $2-4 \mathrm{~cm}$ in length and characteristics of this rice husk could be seen in Table 1. The two other bio-mass adsorbents, orange peel and hard hazelnut shells, were also gathered from Gilan province in 2019. The soil samples were collected from various paddy fields parts, namely with silty clay, silty clay loam, clay loam, and sandy loam textures. Then they were air dried and crushed. Soil characteristics could be identified from Table 2 .

Table 1. Characterization of studied Rice Husk

\begin{tabular}{|c|c|c|c|c|c|c|c|}
\hline $\begin{array}{c}\text { Ele- } \\
\text { ments } \\
\text { analyzed }\end{array}$ & $\begin{array}{c}\mathrm{Si}(\mathrm{mg} / \\
\mathrm{kg})\end{array}$ & $\begin{array}{c}\mathrm{Ca}(\mathrm{mg} / \\
\mathrm{kg})\end{array}$ & $\begin{array}{c}\mathrm{K}(\mathrm{mg} / \\
\mathrm{kg})\end{array}$ & $\begin{array}{c}\mathrm{Mg} \\
(\mathrm{mg} / \\
\mathrm{kg})\end{array}$ & $\begin{array}{c}\text { Water } \\
(\%)\end{array}$ & $\mathrm{pH}$ & Ash (\%) \\
\hline & 102 & 114 & 9801 & 181 & 10.4 & 6.67 & 14.28 \\
\hline
\end{tabular}

Table 2. Particle Size, texture, organic matter content, field capacity (FC) and permanent wilting point (PWP) of the studied soils of paddy-rice farmlands

\begin{tabular}{|l|c|c|c|c|c|c|}
\hline Soil texture & $\begin{array}{c}\text { Sand } \\
(\%)\end{array}$ & Silt (\%) & Clay (\%) & $\begin{array}{c}\text { Organic } \\
\text { matter } \\
(\%)\end{array}$ & $\begin{array}{c}\text { PWP } \\
(\% W)\end{array}$ & $\begin{array}{c}\text { FC } \\
(\% W)\end{array}$ \\
\hline Silty clay & 8 & 43 & 49 & 1.52 & 22.9 & 45 \\
\hline $\begin{array}{l}\text { Silty clay } \\
\text { loam }\end{array}$ & 14 & 44 & 42 & 2.01 & 25.1 & 39 \\
\hline Sandy loam & 71 & 13 & 16 & 0.63 & 6.7 & 13 \\
\hline
\end{tabular}


Native rice paddies were used for many years under conventional management. Two paddy fields were chosen in Gilan, having different textures and bulk density. Then soil was sampled twice, at 15 and 210 days after incorporating $\mathrm{RH}$. Two field experiments were carried out to evaluate rice (Oryza sativa) productivity in mostly silt loam, to which $50 \mathrm{mg} / \mathrm{ha}$ of rice husks were added as a control.

\section{Experiment}

Lead and Cadmium concentrations were determined in treated rice plots with different percentages (w/w\%) of the 3 bio-mass constituents, used as bio-adsorbents and for fortifying the soil. The wet digestion method was used. Some $12 \mathrm{ml}$ concentrated nitric acid (65\% Merck) and $4 \mathrm{ml}$ of Hydrochloric Acid (36.5\%, Merck) were added to $2 \mathrm{~g}$ of each rice sample and placed on a hot plate. There was a gradual increase in heating to insure full digestion and the disappearance of any residual. Cadmium, Lead and Nickel ion concentrations were determined using three replicates with a Varian Vista ICP-AES. A calibration curve was prepared to apply the linear relationship between absorbance and metal concentration in the concentration range being used. The intra-day and inter-day precision and accuracy of the method were determined, under optimal working conditions, by triplicate measurements of known $\mathrm{Cd}, \mathrm{Ni}$ and $\mathrm{Pb}$ concentrations. The first standard stock solutions had a $1.0 \mathrm{mg} / \mathrm{L}$ concentration of each metal and these were used for the preparation of aqueous standard solutions, after appropriate dilution with $10 \%$ nitric acid. The concentration ranges of the working solutions were 0.001-0.1 ppm for all studied metals. Standardized international protocols were followed for the preparation of material and analysis of heavy metals contents by wet digestion method and atomic absorption spectro-photometer. Analysis was based on the annual book of ASTM standards and AOAC (Tajik et al., 2020; Arabian et al., 2020; Shahsavan-Davoudi \& Ziarati, 2020; Hochwimmer et al., 2020; Ziarati \& Hochwimmer, 2018; Alidoost et al., 2016; Gholizadeh \& Ziarati, 2016).

\section{Bio-removal Nickel, Cadmium \& Lead from Rice Samples}

The capacity of bio-mass from agricultural/food and nut wastes for the bio-removal of cadmium and lead ions from contaminated soil of paddy rice samples after the determination of these metals in such rice samples in different states. In the current experiment, $50 \mathrm{mg} / \mathrm{ha}(-1)$ of rice husk were added as a control and rice crops after milling, as white grain rice products ready for consumption were studied in both groups of survey: treated by bio-mass and conventional rice.

The designed study for utilizing Agro/Food waste by maximum potential for removal heavy metals and also enriching the soil and crops were performed as [percentage of (W/W\%)], $S_{1}, S_{2}$ and $S_{3}$ in following formula:

${ }^{*} S_{1}=$ soil fortified by $1 \%$ hazelnut hard shell $+2 \%$ Orange peel $+2 \%$ Husk rice

${ }^{\star} \mathrm{S}_{2}=$ soil fortified by $1 \%$ hazelnut hard shell $+3 \%$ Orange peel $+4 \%$ Husk rice

${ }^{*} \mathrm{~S}_{3}=$ soil fortified by $1 \%$ hazelnut hard shell $+5 \%$ Orange peel $+5 \%$ Husk rice

\section{Results and Discussion}

The present study examined the effect of wastes on the amount of minerals and heavy metals in paddy soils in a Northern Province of Iran. The results of mean zinc content in all rice samples are shown in Figure 1. ANOVA analysis showed that there was a significant difference between all treated and control samples, with all treated samples showing higher content of zinc relative to control samples. An increasing trend was observed in zinc content, with rising amounts of orange peel and rice husk in the fortified soil. Among all rice samples, the rice samples were harvested from soil fortified by $S_{3}$ contained higher amount of zinc followed by $S_{2}$ and $S_{1}$. Therefore, by increasing the amount of orange peel and husk rice from $2 \%$ to $5 \%$ for both, at constant amount of hazelnut shell in $1 \%$, the zinc content in fortified soil was enhanced from 17.605 to $21.313 \mathrm{mg} / \mathrm{kg}$. As the rice samples harvested from soil fortified by $S_{3}$ had higher content of zinc, so these samples analyzed for zinc content after undergoing different process condition including cooking, rinsing and draining. The effect of cooking on brown rice was significant, as the maximum zinc content was belonged to cook brown rice $S_{3}$. Although the content of zinc in rinsing brown rice was higher than drained brown rice, their zinc content was lower than raw brown rice. The results of current study demonstrated the improving effect of cooking on zinc content in these samples. The differences between treated and untreated rice samples were extremely significant, which all treated rice samples displayed considerable higher zinc content than untreated sample with $10.012 \mathrm{mg} / \mathrm{kg}$ zinc content. Similar results were obtained by (Azam et al., 2021), which showed a decrease in mineral content of rice samples with prior washing.

Fortifying paddy soil by the combination of hazelnut shell, orange peel and husk rice led to an increase in iron content of the rice harvested from this soil. Figure 2 shows the mean content on iron in untreated and treated rice samples. The content of iron in rice samples enhanced significantly along with increasing the weight percentage of orange peel and rice husk in combination with constant amount of hazelnut shell. The mean iron concentration recorded in rice samples followed the trend: drained brown rice $S_{3}>$ cooked brown 


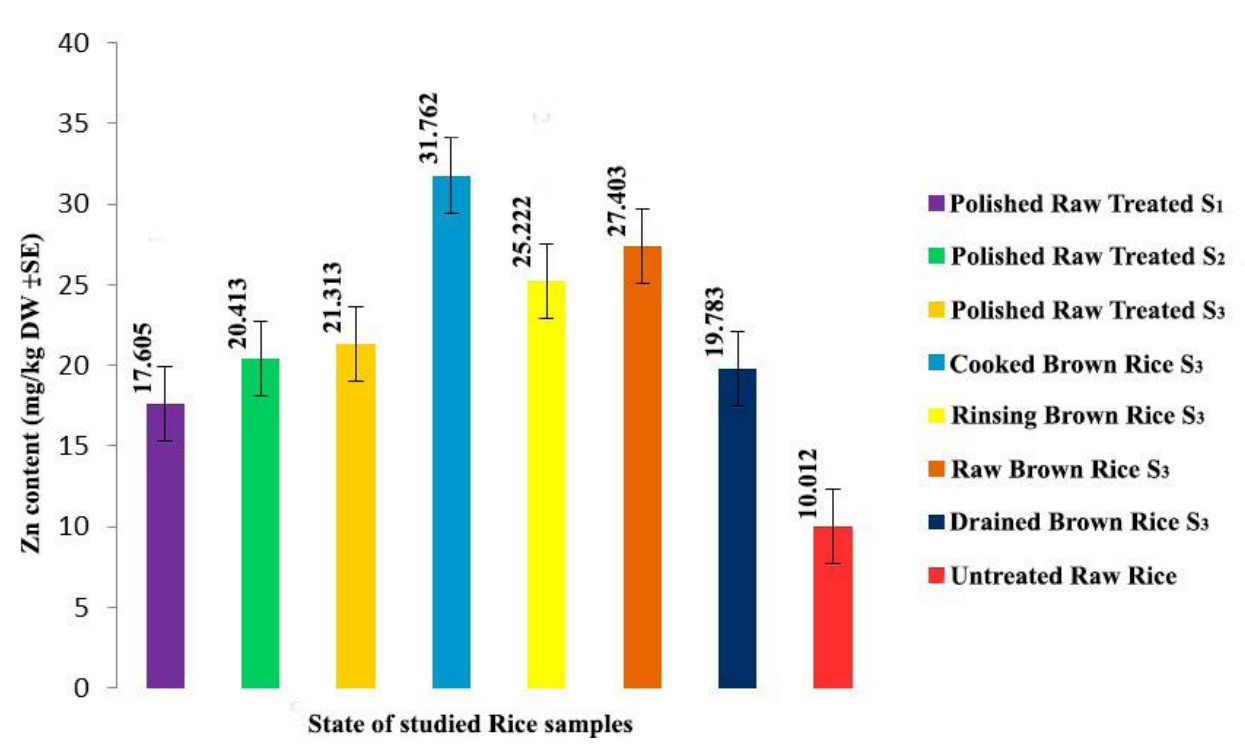

Figure 1. Mean content of zinc content in Oryza Sativa Rice samples

${ }^{\star} S_{1}=$ soil fortified by $1 \%$ hazelnut hard shell $+2 \%$ Orange peel $+2 \%$ Husk rice

${ }^{\star} \mathrm{S}_{2}=$ soil fortified by $1 \%$ hazelnut hard shell $+3 \%$ Orange peel $+4 \%$ Husk rice

${ }^{\star} \mathrm{S}_{3}=$ soil fortified by $1 \%$ hazelnut hard shell $+5 \%$ Orange peel $+5 \%$ Husk rice

${ }^{* *}$ all W/W \%

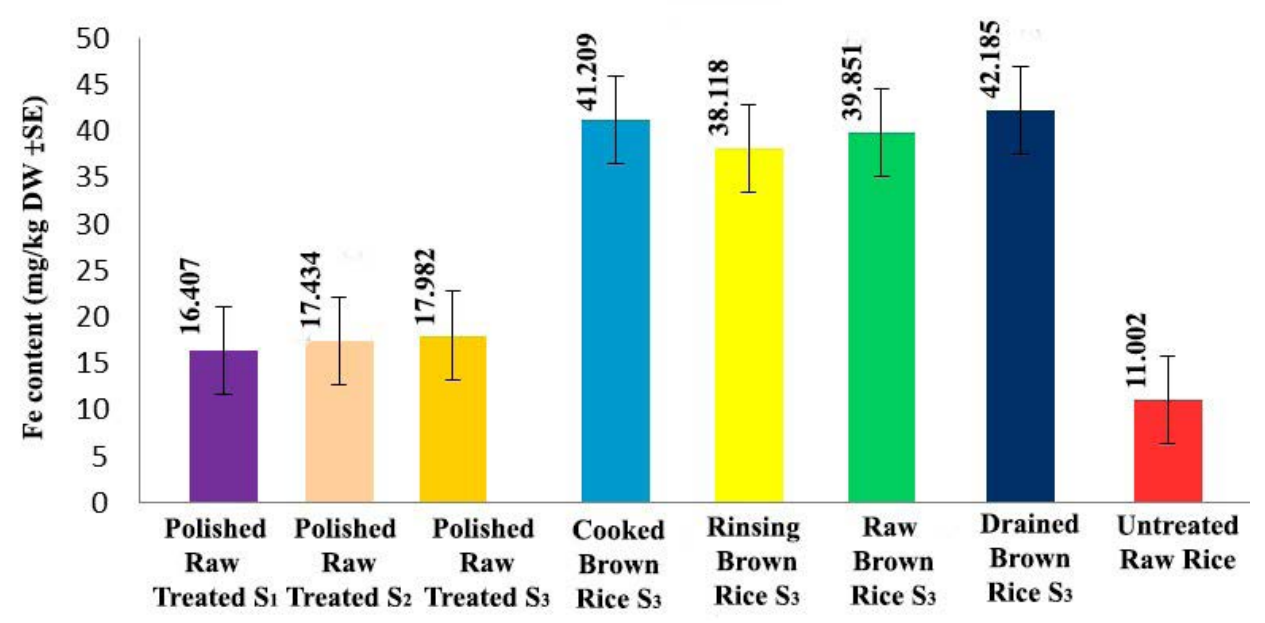

Figure 2. Mean content of Iron in rice samples

${ }^{\star} \mathrm{S}_{1}=$ soil fortified by $1 \%$ hazelnut hard shell $+2 \%$ Orange peel $+2 \%$ Husk rice ${ }^{*} S_{2}=$ soil fortified by $1 \%$ hazelnut hard shell $+3 \%$ Orange peel $+4 \%$ Husk rice ${ }^{\star} S_{3}=$ soil fortified by $1 \%$ hazelnut hard shell $+5 \%$ Orange peel $+5 \%$ Husk rice $* *$ all W/W \%

rice $S_{3}>$ raw brown rice $S_{3}>$ rinsing brown rice $S_{3}>$ polished raw treated $S_{3}>$ polished raw treated $S_{2}>$ polished raw treated $S_{1}>$ untreated raw rice. The polished raw treated $\mathrm{S}_{3}$ with $17.982 \mathrm{mg} / \mathrm{kg}$ iron content, showed higher content of iron towards the other polished samples. However, the differences were not significant between iron content in polished rice, which was harvested from soil fortified by $S_{1}$, $\mathrm{S}_{2}$ and $\mathrm{S}_{3}$.

The effect of different processing condition on brown rice samples harvested from soil fortified with $S_{3}$ investigated by analyzing the iron content in the samples. With mean concentration of iron $42.185 \mathrm{mg} / \mathrm{kg}$, drained brown rice showed the highest amount of iron, against the other processed and also raw rice samples. The minimum iron content between processed samples was related to the rinsing sample with $38.118 \mathrm{mg} / \mathrm{kg}$, which was lower than unprocessed rice sample (raw rice $S_{3}$ ). Cooking had a positive effect on iron content, where the iron level in cooked brown rice was higher than raw rice. The rice samples harvested from fortified soil by $S_{1}$ showed the minimum amount of 
iron $(16.407 \mathrm{mg} / \mathrm{kg})$, however, it was significantly higher than untreated rice with $11.002 \mathrm{mg} / \mathrm{kg}$ iron content. Zinc and iron are the critical minerals, which are necessary for human health (Azam et al., 2021). The higher amount of zinc and iron in raw brown rice, compared to untreated rice samples, proved the efficiency of combined hazelnut shell, orange peel and husk rice in paddy soil fortification and absorption of these minerals by rice cultivated in this soil. The increase in soil minerals, and consequently in rice, may be due to adding the orange peel to soil, as the presence of large amounts of iron and zinc in the orange peel was shown earlier (Czech et al., 2020). The polishing process was probably responsible for the extremely higher amounts of zinc and iron in raw brown rice, harvested from agricultural soil fortified by $S_{3}$ against the polished raw treated samples. Polished rice is produced by removing the bran layer from the kernel, which reduces minerals (Majumder et al., 2019). The results of a study conducted by (Majumder et al., 2019) showed an extreme reduction of zinc and iron in polished rice.

The other advantage of adding these wastes to paddy soil is reduction or elimination of heavy metals. The maximum permissible limit of cadmium and lead in rice is about 0.06 $\mathrm{mg} / \mathrm{kg}$ and $0.15 \mathrm{mg} / \mathrm{kg}$, respectively (INSO, 2013). The concentration of the heavy metals including cadmium and lead in the untreated rice sample (control) was $0.434 \mathrm{mg} / \mathrm{kg}$ for cadmium and $2.015 \mathrm{mg} / \mathrm{kg}$ for lead, which was higher than the maximum recommended Iranian level by standard. The effect of different formulation of combining Agro/Food wastes based on removing heavy metals are shown in Figure 3 and 4. Based on Figure 3, all different levels of hazelnut shell, orange peel and rice husk had a significant effect on cadmium content in rice samples. The differences between polished rice samples from soil fortified by $S_{1}$ and $S_{2}$ were not significant. Although polished rice samples from soil

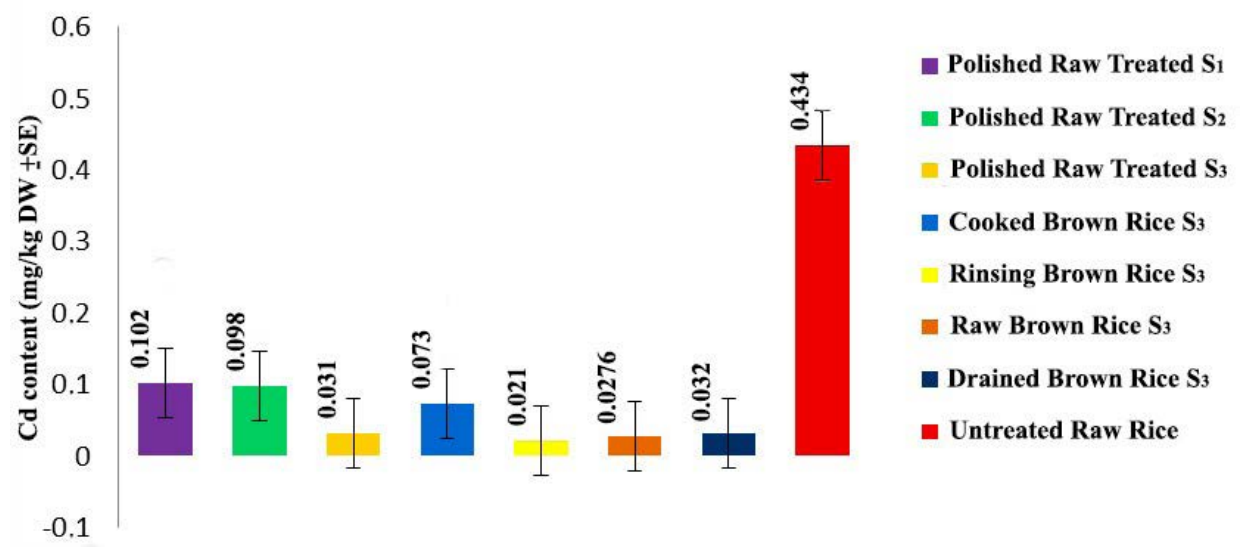

Figure 3. Mean content of cadmium in rice samples

${ }^{\star} \mathrm{S} 1=$ soil fortified by $1 \%$ hazelnut hard shell $+2 \%$ Orange peel $+2 \%$ Husk rice

${ }^{\star} \mathrm{S} 2=$ soil fortified by $1 \%$ hazelnut hard shell $+3 \%$ Orange peel $+4 \%$ Husk rice

${ }^{\star} \mathrm{S} 3=$ soil fortified by $1 \%$ hazelnut hard shell $+5 \%$ Orange peel $+5 \%$ Husk rice

$* *$ all $\mathrm{W} / \mathrm{W} \%$

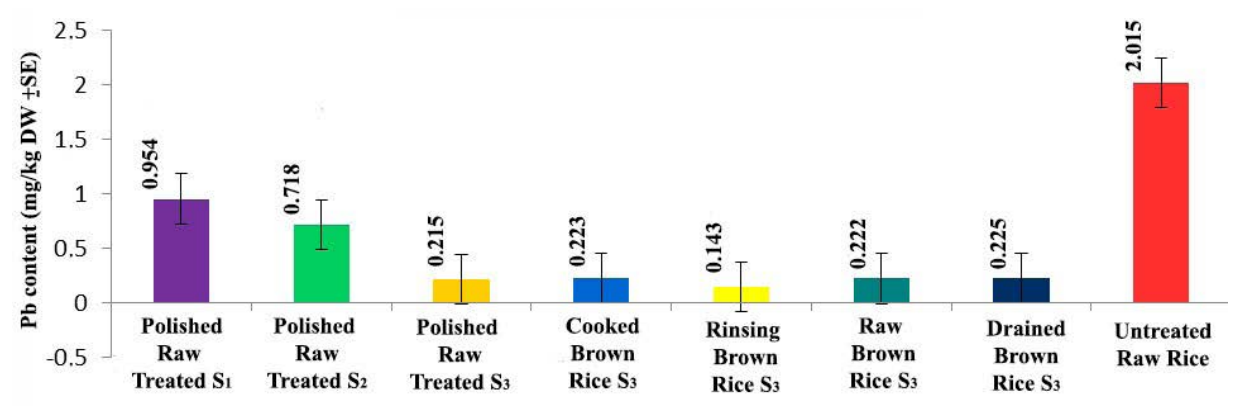

Figure 4. Mean content of Lead in rice samples

${ }^{*} S_{1}=$ soil fortified by $1 \%$ hazelnut hard shell $+2 \%$ Orange peel $+2 \%$ Husk rice

${ }^{\star} \mathrm{S}_{2}=$ soil fortified by $1 \%$ hazelnut hard shell $+3 \%$ Orange peel $+4 \%$ Husk rice

${ }^{\star} \mathrm{S}_{3}=$ soil fortified by $1 \%$ hazelnut hard shell $+5 \%$ Orange peel $+5 \%$ Husk rice

${ }^{* *}$ all $\mathrm{W} / \mathrm{W} \%$ 
fortified by $S_{1}$ and $S_{2}$ combinations showed significant lower cadmium content against untreated sample, their cadmium content was higher than the maximum recommended level in Iran. The $S_{3}$ combination (1\% hazelnut, 5\% orange peel and $5 \%$ rice husk) had an extremely significant effect on cadmium content in polished rice samples. This raw polished treated $S_{3}$ with $0.031 \mathrm{mg} / \mathrm{kg}$ DW cadmium content was not toxic for human consumption. The amount of cadmium in cooked brown rice $S_{3}$ was $0.073 \mathrm{mg} / \mathrm{kg}$, which is higher than $0.06 \mathrm{mg} / \mathrm{kg}$ permissible content. Similar results were obtained by (Naseri et al., 2014); they showed the reduced efficiency of cooking on heavy metals. The effect of rinsing and draining on cadmium content was significant. All treated samples showed considerably lower contents of cadmium against untreated samples.

Figure 4 gives the concentration of lead in untreated, raw-treated and process-treated rice samples as mean \pm standard deviation. Comparing the average contents of lead, all samples showed that an increase for the orange peel and husk rice, with a constant amount of hazelnut shell having a significant effect on lead content in the rice harvested from fortified soil.

All polished raw samples, which treated by $S_{1}, S_{2}$ and $S_{3}$, showed lower lead content than maximum recommended Iranian level. At a fixed amount of hard hazelnut shell content ( $1 \%)$, by lifting the orange peel and husk rice from $2 \%$ in both to $3 \%$ and $4 \%$, respectively, the lead content was decreased from 0.954 to $0.718 \mathrm{mg} / \mathrm{kg}$. The soil fortified with $\mathrm{S}_{3}$ combination ( $1 \%$ hard hazelnut shell, $5 \%$ orange peel and $5 \%$ husk rice) showed the minimum lead content. All different percentage combination of wastes, used for soil fortification $\left(S_{1}, S_{2}\right.$ and $\left.S_{3}\right)$, showed considerable potential in lead removal/immobilization from soil. The data obtained from measuring the lead content in rice samples processed under mentioned conditions, showed rinsing as the more effective condition in elimination of lead from samples. The cooked and drained brown rice samples with 0.223 and $0.225 \mathrm{mg} / \mathrm{kg}$ lead content, respectively, showed no significant difference compared to the raw rice sample with $0.222 \mathrm{mg} / \mathrm{kg}$ lead content. The lead content in all fortified rice samples showed extreme differences against untreated rice sample with 2.015 $\mathrm{mg} / \mathrm{kg}$ lead content. Comparison of the effect of different processing conditions on lead and cadmium, identified rinsing as the more effective condition for reducing heavy metals in rice samples. The effect of rinsing maybe related to washing the grains by water. These results were in accordance to the results obtained by Ziarati \& Azizi, which showed the reduction in cadmium and lead content by rinsing (Ziarati \& Azizi, 2014). As major concern in soil and food pollution, specifically in the rice cultivation, is heavy metals such as cadmium, mercury, lead and arsenic. These contaminate the soil and subsequently make plants toxic (Zulkafflee et al.,
2019). All tested waste combinations used to immobilize/ remove heavy metals from rice soils had a very significant effect on cadmium and lead content. The important thing is that the higher the content of this waste provided the higher efficiency. The high sorption performance of hazelnut shells in removing heavy metals has been revealed (Zulkafflee et al., 2019). Their results showed a higher removal potential of hazelnut shell of about $98 \%$ for cadmium and $97 \%$ for lead from contaminated solutions. The removal behavior of lead ions using rice husk was proved by (Asrari et al., 2011), in which they used rice husk to remove lead from wastewater. Also the sequestration potential of rice bran for cadmium was reported by (Kadirvelu et al., 2001).

\section{Conclusions}

The agricultural soil was fortified with various combinations of hard hazelnut shells, orange peel and rice husks. The mean level of minerals absorbed by rice samples was determined from laboratory measurements. Heavy metals removed from the soil were determined in $\mathrm{mg} / \mathrm{kg}$ DW. Based on the obtained data, it was found that soil fortified with S3 (1\% of hard hazelnut shells, $5 \%$ of orange peel and $5 \%$ of rice husks) yielded rice samples with higher content of zinc and iron compared to untreated rice samples. This combination of identified wastes showed good potential for immobilizing/ eliminating or reducing heavy metals to less than permissible limits. Therefore, the use of a combination of hazelnut shells, orange peel and rice husks could be an effective strategy to both introduce new micronutrients into rice grain and remove heavy metals.

\section{Acknowledgements}

Supports from Medicinal Chemistry Department, Pharmacy and Pharmaceutical Sciences Faculty, Tehran Medical Sciences, Islamic Azad University is gratefully acknowledged.

\section{References}

Alidoost F., Lahiji S., Ziarati P. \& Jafarpour A., 2016, Potential of Rice Husk Biosorption in Reduction of Heavy Metals from Oryza sativa Rice. Bio-sciences Biotechnology Research Asia 13(4): 2231-2237.

Aleshkov A., Ivashkin M., Zhebo A. \& Burik M., 2020, Technology and characteristics of boiled sausages enriched with dietary fibers of Plantago Psyllium 1. Biointerface Research in Applied Chemistry 10(4): 5715-5723. https://doi.org/10.33263/BRIAC104.715723 
Alloway B.J., 2009, Soil factors associated with zinc deficiency in crops and human. Environmental Geochemistry and Health 31: 537-548.

Arabian S., Ziarati P. \& Sawicka B., 2020, Waste Herbal and Black Tea as a Novel Adsorbent for Detoxification of Pharmaceutical Effluent. J Med Discov 5(3): 1-15.

Arora M. \& Kaur P., 2017, Phyto-chemical screening of orange peel and pulp. International Journal of Research in Engineering and Technology 12(02): 517-522.

Asrari E., Tavallali. H. \& Hagshenas M., 2011, Removal of $\mathrm{Zn}$ (II) and $\mathrm{Pb}$ (II) ions Using Rice Husk in Food Industrial Wastewater. Journal of Applied Science and Environmental Management 14(4): 159-162.

Azam M.M., Padmavathi S., Fiyaz R.A., Waris A., Ramya K.T. \& Neeraja C.N., 2021, Effect of different cooking methods on loss of iron and zinc micro-nutrients in fortified and non-fortified rice. Saudi Journal of Biology Sciences 28(5): 2886-2894.

Biswal P., Pal A. \& Das A.P., 2019, Molecular identification of native lactic acid bacteria isolated from curd samples with probiotic potential. Biointerface Research in Applied Chemistry 9(6): 4691-4597.

Cruz Lopes L.P., Martins J., Esteves B. \& Teixeira De Lemos L., 2012, New products from hazelnut shell. Proceeding of ECOWOOD'2012: Towards Forest Products and Processes with Lower Environmental Impact, p. 83-90. https:// www.academia.edu/14831911/NEW_PRODUCTS _FROM_HAZELNUT_SHELL

Czech A., Zarycka E., Yanovych D., Zasadna Z., Grzegorczyk I. \& Klys S., 2020, Mineral content of the pulp and peel of various citrus fruit cultivars. Biological Trace Element Research 193: 555-563.

Dar S.A., Singh S.P., Patel P.S. \& Wani S.H. (eds), 2019, Advances in agricultural research and innovations. MESP-International \& Mind Gates Softech Solutions. https://mespinternational.com

Dunna V. \& Roy B., 2013, Rice (Oryza sativa L.), [in:] B. Roy (ed.), Breeding, Biotechnology and Seed Production of Field Crops, Chapter 4. New India Publishing Agency, New Delhi, p. 71-122.

Fatahi A., Ziarati P., Jafarpour A. \& Cruz-Rodriguez L., 2020, Heavy Metal Removal from Edible Leafy Vegetable by Low Cost Novel Adsorbents: Hazelnut Shell. J Sci Discov 4(2): jsd20039. DOI:10.24262/jsd.4.2.20039.

Gholizadeh E. \& Ziarati P., 2016, Remediation of Contaminated Rice Farmlands Soil and Oryza sativa Rice Product by Apple Pomace as Adsorbent Remediation of Contaminated Rice Farmlands Soil and Oryza sativa Rice Product by Apple Pomace as Adsorbent. Bio-sciences Biotechnology Research Asia 13(4): 2245-2253.

Glushankova I., Ketov A., Krasnovskikh M., Rudakova L.
\& Vaisman I., 2018, Rice hulls as a renewable complex material resource. Resources 7(31): 1-11.

Hebda T., Brzychczyk B., Francik S. \& Pedryc N., 2018, Evaluation of suitability of hazelnut shell energy for production of bio-fuels. 17th International Scientific Conference on Engineering for Rural Development, 23-25 May 2018, Jelgava, Latvia, p.1860-1865.

Hochwimmer B., Ziarati P., Selinus O., Elwej A., CruzRodriguez L.D., Lambert Brown D., Zayas Tamayo A.M., Moradi M. \& Cruz-Rodriguez L.A., 2020, Predictive Geological Tool of Type 3 Diabetes (Alzheimer's Disease): The Polygonal Vortex Mineralisation Model a Medical Geology Perspective. Journal of Diabetes and Endocrinology Research 2(2): 1-15.

INSO, Iranian National Standardization Organization, 2013, http://isiri.org/portal/File/ShowFile.asp.

Kadirvelu K., Namasivayam C. \& Thamaraiselve K., 2001, Removal of heavy metal from industrial wastewaters by adsorption on to activated carbon prepared from an agricultural solid waste. Bioresource Technology 76: 63-65.

Kennedy G., Burlingame B. \& Nguyen V.N., 2003, Nutritional contribution of rice and impact of biotechnology and biodiversity in rice-consuming countries. AGRIS. https://agris.fao.org/agris-search/search.do?recordID =XF2004415363

Liyanage Ch. \& Hetteriarachchi M., 2011, Food fortification. Ceylon Medical Journal 56(2): 124-127.

Mahmoud E., Kader N.A.E., Robin P., Corfini N.A. \& Rahman L.A.E., 2009. Effects of Different Organic and Inorganic Fertilizers on Cucumber Yield and Some Soil Properties. World J. Agricult. Sci. 5: 408-414.

Majumder S., Datta K. \& Kumar Datta S., 2019, Rice Biofortification: High Iron, Zinc, and Vitamin-A to Fight against 'Hidden Hunger'. Agronomy 9(983): 1-22.

Muthayya S., Hall J., Bagriansky J., Sugimoto J., Gundry D., Matthias D., Prigge S., Hindle P., Moench-Pfanner R. \& Maberly G., 2014, Rice fortification: An emerging opportunity to contribute to the elimination of vitamin and mineral deficiency worldwide. Food and Nutrition Bulletin 33(4): 296-307.

Naseri M., Rahmanikhah Z., Beiygloo V. \& Ranjbar S., 2014, Effect of Two Cooking Methods on the Concentration of Some Heavy Metals (Cadmium, Lead, Chromium, Nickel and Cobalt) in Some Rice Brands Available in Iranian Market. Journal of Chemical Health Risks 4(2): 65-72.

Rohman A., Helmiyati S., Hapsari M. \& Setyaningrum L., 2014, Rice in health and nutrition. International Food Research Journal 21(1): 13-24.

Shahsavan-Davoudi M.H. \& Ziarati P., 2020, Green Method for Cadmium Removal from Pharmaceutical Effluent 
Laboratories by Grapefruit Peel. J Sci Discov 4(2): jsd20039. DOI:10.24262/jsd.4.2.20039

Tajik S., Ziarati P. \& Cruz-Rodriguez L., 2020, Coffee Waste as Novel Bio-Adsorbent: Detoxification of Nickel from Contaminated Soil and Coriandrum Sativum. Journal of Bio-science \& Biomedical Engineering 1(3): 1-11.

Ziarati P. \& Azizi N., 2014, Consequences of Cooking Method inessential and Heavy Metal Contents in Brown and Polished Alikazemi Rice. International Journal of Plant, Animal and Environmentally Sciences 4(2): 280-287.
Ziarati P. \& Hochwimmer B., 2018, The Medical Geology and Discovery of Taranjebin Manna as a Hyper Selenium Accumulator; Biomedical and Ethno-Medical Efficacy Links to Calc-alkaline and Alkalic Tethyan Magmatic Arcs. J Agri Sci Food Res 9: 234.

Zulkafflee N.S., Redzuan N.A.M., Hanafi Z., Selamat J., Ismail M.S., Praveena S.M. \& Abdull Razis A.F., 2019, Heavy Metal in Paddy Soil and its Bio-availability in Rice Using In-Vitro Digestion Model for Health Risk Assessment. International Journal of Environmental Research and Public Health 16(4769): 1-12. 